\title{
Stomatal, Proline, and Leaf Water Status Characters of Some Cocoa Clones (Theobroma cacao L.) on Prolonged Dry Season
}

\author{
Fakhrusy Zakariyya $^{\left.1^{*}\right)}$, Bayu Setyawan ${ }^{1)}$, and Agung Wahyu Susilo ${ }^{1)}$ \\ ${ }^{1)}$ Indonesian Coffee and Cocoa Research Institute, Jl. PB Sudirman No. 90, Jember, Indonesia \\ ${ }^{*}$ Corresponding author: fakhrusy.zakariyya@gmail.com \\ Received: 15 July 2017 / Accepted: 28 July 2017
}

\begin{abstract}
ENSO (El Nino Southern Oscillation) occurring in 2015 in Indonesia caused drought stress and the decrease in the percentage of production and even death of plants. One effective and relatively inexpensive way of reducing damage and economic losses due to drought is the availibility of tolerant cocoa. The objective of this research was to obtain tolerant clones based on morpho-physiological characters under drought stress. The experiment was conducted in Kaliwining Experimental Station of Indonesian Coffee and Cocoa Research Institute (ICCRI) during dry season (El Nino period with 5 consecutive dry months, from May to October 2015). Stomata, proline, leaf water status was measured at the peak of dry season on tested cocoa clones. The cocoa clones that predicted tolerant against to drought stress were KW 641, KW 514, KW 535, KW 619, and KW 516, whereas the cocoa clones that predicted susceptible under drought stress were KW 609, KW 614, KW 635, KW 606, and KW 651. The treatment clones had higher values of RWC, leaf proline content, narrower width and length of stomata openings, but smaller value of WSD compared to susceptible clones. Meanwhile, the character of leaf thickness might not significanly different to the character of drought tolerance.
\end{abstract}

Keyword: Cocoa, El Nino, drought, stomata, leaf water status, proline, Theobroma cacao

\section{INTRODUCTION}

The threat of climate change is a serious problem for the plantation sector, especially for cocoa commodity. Cocoa is a plant that is sensitive to climate change. An example of climate change phenomenon that potentially threats to decrease production are the occurrence of the El Nino. ENSO (El Nino Southern Oscillation) is associated with a band of warm ocean water that develops in the central and east-central equatorial Pacific. El Nino will have an impact on longer dry season than usual and potentially cause drought stress for cocoa plantation.

Drought-related El Nino could significantly reduce cocoa production in some areas. Statistical and econometric analyses revealed that El Niño events had a significant negative impact on cocoa production. It was estimated that El Niño reduces cocoa production, on average, by $2.4 \%$ at world level. As predicted, Ecuador was the country suffering the most, with cocoa production declining by over $6 \%$ on average (ICCO, 2010). The socioeconomic study added that the drought associated with ENSO in Nigeria could reduce cocoa production by $6.2 \%$ (Oyekale, 2015; Keil et al., 2008), while in Indonesia, ICCO (2010) reported a decrease in production due to ENSO of $2.4 \%$. Sakiroh et al. (2015) reported that drought stress related to El Nino directly lead to disruption of photosynthesis and plant metabolism, the 
occurrence of flowers abortion, bud dormancy and plant death. In some other cocoa producers countries, production declined due to abiotic factors to be the focus of the problem, especially drought.

Research on cacao and drought in Indonesia has been done since 1970s, (Wood, 1975; Abdoellah, 1997; Soedarsono et al., 1997; Brataningtyas, 2010; Kacou et al., 2016; Schwendenmann et al., 2016), but it is still not enough to solve the problem of drought in future because more extreme of weather due to global warming. Studies are needed to obtain adaptation and mitigation technologies for cocoa plantation in overcoming drought stress. One effective and relatively inexpensive way of suppressing the damage and economic losses caused by drought is to plant resistant cacao clones (Abdoellah, 1997; Sakiroh et al., 2015).

The efforts that can be adopted in obtaining dry-resistant cocoa clones is to figure out the physiological and morphological characters of the plant in overcoming the stress. In general, the mechanism of plants under drought stress is to limit water loss through transpiration. In seedling phase, transpiration of cocoa plants under stress decrease $38-40 \%$ than under normal condition (Chibuike \& Daymond, 2015; Kacou et al., 2016; Rada et al., 2005). This is as plant strategy and mechanism in conserving water in the body of the plant. The water conditions can be controlled in leaves through stomata behaviour such as stomata aperture and number of stomata. Winaryo et al. (1997) used the number of stomata in determining cocoa resistant clones to drought stress. Beside it, the status of water in the plant body can be reflected through the relative water content and water-saturation deficit in cocoa plant tissue (Fitter \& Hay, 1981). Abdoellah et al. (1996) determined the resistance of cocoa seedlings to drought through the relative water content and water saturation deficit parameters. In addition to stomata, proline is also used as an indicator of plant resistance to drought stress. Proline is used as an osmotic adjustment under water deficit condition. The idea to select drought tolerant genotypes and to identify morphophysiological characters was that discriminating drought stress will accelerate the breeding cycle and helps for an early screening of germplasm collections.

\section{MATERIALS AND METHODS}

The experiment was conducted in Kaliwining Experimental Station, of ICCRI in Jember, during dry season (El Nino period with 5 months of dry months) from May to October 2015 (Table 1). This study was designed using a randomized block design with one factor with 3 replications. The cocoa plant used were 10 years old cacao plants propagated through top grafting method. The bud woods grafted were KW 609, KW 619, KW 635, KW 641, KW 535, KW 514, KW 606, KW 614, KW 516, and KW 651.

Plant maintenance includes pruning, pest and disease control, and fertilization followed farming standard procedure. Variables observed included environmental aspects, i.e. soil moisture content using gravimetric method, temperature and rainfall taken from ICCRI Climatology Station, and soil $\mathrm{pF}$ measured using pressure plate extractor tool. Based on soil $\mathrm{pF}$ measurement, the value of $\mathrm{pF}$ 2.54 (field capacity status) was $35.18 \%$ and $\mathrm{pF} 4.2$ (permanent wilting point status) was $23.07 \%$.

Stomata was observed with a microscope at the peak of dry season. The abaxial side of the cocoa leaf was smeared with transparent nail polish along $3 \mathrm{~cm}$ long until dry. After dry then the nail polish was picked up by using masking tape and affixed on top of the preparation. In the dry nail polish attached epidermal layer cells and stomata. 
Glass objects immediately closed with glass objects and stomata observed under a microscope with magnification 40 times. Number of stomata was calculated in every single microscope field of view. Width, length and diameters of openings were observed using Image Raster. Relative water content (RWC) and water saturation deficit (WSD) were calculated based on Banister (1976) with the equation:

$$
\begin{aligned}
& \operatorname{RWC}(\%)=\frac{100(\mathrm{~W} f-\mathrm{W} d)}{(\mathrm{W} s-\mathrm{W} d)} \\
& \operatorname{WSD}(\%)=\frac{100(\mathrm{~W} f-\mathrm{W} d)}{(\mathrm{Ws}-\mathrm{Wd})}
\end{aligned}
$$

RWC is the relative water content (\%), WSD is the water saturation deficit, $\mathrm{W} f$ is the fresh leaf weight, $\mathrm{Wd}$ is the dry leaf weight, and Ws is the weight of the leaf after fully filled with water. The thickness of leaf was measured using caliper. The observed leaves were the fully developed leaves or the $3^{\text {rd }}$ leaf of flush.

Proline observation was done by Bates method (1973). Leaves of $0.5 \mathrm{~g}$ were crushed with mortar then mixed $10 \mathrm{~mL} 3 \%$ sulfosalicyllic acid then filtered with filter paper.
Two milliliters of filtrate was mixed with $2 \mathrm{~mL}$ of ninhydrin acid and $2 \mathrm{~mL}$ glacial acetic acid in test tube and heated to $100^{\circ} \mathrm{C}$ for one hour. The reaction was ended by inserting the test tube into a glass containining ice. The solution was extracted with $4 \mathrm{~mL}$ toluene, then shaken with vortex for 15-20 seconds to form two layers. The top layer of red that contained proline was taken with a pipette and then measured its absorbance with a spectrophotometer at a wavelength of $520 \mathrm{~nm}$. The content of proline was determined by the reading of pure proline standard solution. Preparation of ninhydrin acid was $1.25 \mathrm{~g}$ of ninhydrin plus $30 \mathrm{~mL}$ glacial acetic acid and $20 \mathrm{~mL}$ of $6 \mathrm{M}$ phosphoric acid $\left(\mathrm{H}_{3} \mathrm{PO}_{4}\right)$ was heated to dissolve. Ninhydrin acid was made by adding $1 \mathrm{~g}$ of ninhydrin with $24 \mathrm{~mL}$ of glacial acetic acid boiled to blue. A total of $2.5 \mathrm{~mL}$ of phosphoric acid plus $5.5 \mathrm{~mL}$ of distilled water were added to the ninhydrin solution and heated until dissolved. The observed data of several observation variables were then analyzed using analysis of variant (ANOVA) with $\alpha=5 \%$. If the result of variance analysis was obtained that $\mathrm{F}$ hit $>\mathrm{F}$ table means there was significant difference between treatments, then continued with DMRT with $\alpha=5 \%$ (Gomez \& Gomez, 1995).

Table 1. Distribution of rainfall, maximum temperature, minimum temperature, and humidity at the time of observation

\begin{tabular}{|c|c|c|c|c|c|}
\hline \multirow{2}{*}{ Month } & \multirow{2}{*}{$\begin{array}{c}\text { Rainfall } \\
\text { (Average of year 1980-2015) } \\
(\mathrm{mm})\end{array}$} & \multirow{2}{*}{$\begin{array}{c}\text { Rainfall } \\
(\text { Year 2015) } \\
(\mathrm{mm}) \\
\end{array}$} & \multicolumn{2}{|c|}{ Temperature $\left({ }^{\circ} \mathrm{C}\right)$} & \multirow{2}{*}{$\mathrm{RH}(\%)$} \\
\hline & & & Max & Min & \\
\hline January & 337.11 & 287.0 & 32.3 & 23.0 & 88 \\
\hline February & 243.17 & 403.0 & 32.7 & 22.3 & 90 \\
\hline March & 249.83 & 255.0 & 32.2 & 22.7 & 89 \\
\hline April & 212.31 & 422.0 & 33 & 22.6 & 89 \\
\hline May & 98.89 & 30.0 & 32.6 & 20.8 & 89 \\
\hline June & 47.75 & 44.0 & 31.8 & 19.8 & 88 \\
\hline July & 32.78 & 3.0 & 31.3 & 19.2 & 88 \\
\hline August & 14.39 & 0 & 32 & 19.1 & 87 \\
\hline September & 33.47 & 0 & 32.4 & 18.9 & 85 \\
\hline October & 107.46 & 5.5 & 34 & 20.5 & 85 \\
\hline November & 196.31 & 120.0 & 33.8 & 22.4 & 86 \\
\hline December & 325.78 & 119.0 & 32.6 & 22.9 & 87 \\
\hline Total & 1899.24 & 1688.5 & - & - & - \\
\hline
\end{tabular}
(Kaliwining, January - December 2015) 


\section{RESULTS AND DISCUSSION}

Table 1 showed that El Niño period in 2015 was May-October 2015. It shows that the dry months period in the research location based on the Schmidt \& Ferguson classification (1950) was 5 months. Ideally, cocoa plants can grow well on land with sufficient rainfall (1500-2000 mm/year or average $125 \mathrm{~mm} / \mathrm{month}$ ) and dry months of no more than three months based on Schmidt $\&$ Ferguson classification (Baon, 1988). The uneven rain distribution conditions throughout the year lead to drought stress in plants (Mommer et al., 1999). Temperatures in MayAugust 2015 showed relatively the same value as other months, but relative humidity $(\mathrm{RH})$ in the dry period showed a difference in previous months where $\mathrm{RH}$ decreased by $1-4 \%$ compared to wet months.

The dry month period had an impact on moisture content during the observation period. In the dry period (August 2015), soil moisture content was $28.6 \%$. Based on $\mathrm{pF}$ status, moisture content at the peak of the dry month period showed close to permanent wilting point $(\mathrm{pF} 4.2)$ that was $23.07 \%$. This reflected the conditions of drought stress period in August 2015.

\section{Morphological and Physiological Traits}

Stomata is a pore, found in the epidermis of leaves, stems, and other organs, that facilitates gas exchange. The pore is bordered by a pair of specialized parenchyma cells known as guard cells that are responsible for regulating the size of the stomatal opening. Stomatal closure occur when the two guard cells surrounding the stomatal opening lose turgor pressure and close the opening (Outlaw, 2003). Arve et al. (2011) demonstrated that there were many signals that induced stomatal closure, among these the best known signal was probably ABA. In the signaling pathway towards stomatal closure there are several secondary messengers, such as $\mathrm{Ca}^{2+}, \mathrm{H}_{2} \mathrm{O}$ and $\mathrm{NO}$ that contribute to the stomatal closure. Passive loss of turgor pressure also results in stomatal closure. Fitter \& Hay (1981) mentioned that stomata aperture was a main strategy to conserve water in plant. The stomata character can be seen from the number of stomata, width, length, diameter, and ratio of length/width of stomatal openings.

Table 2 demonstrated the stomatal traits at the peak of dry month. The highest number of stomata was found in clones KW 609 and KW 606 which was significantly different compared to KW 641, KW 516, KW 535, KW 651. However, the lowest number of stomata was found in KW 641 and KW 516. Based on this, clones that have small number of stomata can be expected to have resistance to drought. Plants considered to be drought tolerant generally have less stomata compared to non-tolerant plants (Winaryo et al, 1996; Lestari, 2005). Opening and closing of stomata aperture are very important mechanisms that plants used to control diffusion of gasses and $\mathrm{H}_{2} \mathrm{O}$ in and out of leaves. Ideally, stomata must be sufficiently open to allow enough $\mathrm{CO}_{2}$ to diffuse in, but sufficiently closed to prevent too much evaporative loss of $\mathrm{H}_{2} \mathrm{O}$ (transpiration) (Johnson, 2007).

Based on this study, the narrowest stomatal width and lowest stomatal length aperture was found on KW 641, KW 614, KW 514, and KW 516, meanwhile, the widest stomatal width aperture was on KW 609, KW 635, and KW 651 (Table 2). Interestingly, the result showed that stomatal diameter and width/ length ratio was not significantly different between clones, and according to Johnson (2007) if the ratio value $>0.23$ meaning that the stomata still open. Thus, with this stomatal opening condition, it shows the transpiration and gas diffusion is still running, but the limitation of the loss transpiration can be seen from the width and length of stomatal opening. These changes of size and stomatal 
opening are related with stomatal density, especially as conservation method during drought stress (Lawson \& Blatt, 2014). Interestingly, the plant that has lower densities with the larger stomatal size can decrease transpiration, higher growth rates, and larger biomass (Doheny-Adams et al., 2012). Under severe water deficits resulting from high evaporative demand and/or dry soil, plants rely upon full stomatal closure and a highly water impermeable leaf cuticle to minimize water loss (McDowell et al., 2008; Drake et al., 2013). During the dry season, the plasticity of stomatal opening was determined by length and width of stomatal openings, which caused by the pressure of turgor in stomatal tissue.

Figure 1 showed leaf thickness at the time changes of cocoa during drought stress. Leaf thickness represents specific leaf area. In dry periods, the measurement of leaf thickness will show water status in leaves and gas exchange (Galmes et al., 2013). The leaf thickness also can determine water capacity in the leaf, which determine the tolerances against drought (Marechaux et al., 2015). Figure 2 demonstrated the variance of leaf thickness from several cocoa clones. High leaf thickness was obtained by KW 641, KW 609, and KW 514 .

Table 2. Stomatal traits of several cocoa clones during prolonged dry season

\begin{tabular}{|c|c|c|c|c|c|}
\hline Clones & Number of stomata & $\begin{array}{l}\text { Width of stomatal } \\
\text { aperture }(\mu \mathrm{m})\end{array}$ & $\begin{array}{l}\text { Length of stomatal } \\
\text { aperture }(\mu \mathrm{m})\end{array}$ & $\begin{array}{l}\text { Stomatal diameter } \\
(\mu \mathrm{m})\end{array}$ & $\begin{array}{c}\text { Width/length } \\
\text { aperture of stomata } \\
\text { ratio }\end{array}$ \\
\hline KW 514 & $114.67 \mathrm{bc}$ & $1.4 \mathrm{bc}$ & $2.7 \mathrm{~cd}$ & $5.2 \mathrm{a}$ & $0.52 \mathrm{a}$ \\
\hline KW 516 & $57.33 \mathrm{f}$ & $1.8 \mathrm{ab}$ & $2.7 \mathrm{~cd}$ & $4.8 \mathrm{a}$ & $0.66 \mathrm{a}$ \\
\hline KW 535 & 85.33 def & $1.5 \mathrm{abc}$ & $3.3 \mathrm{abc}$ & $5.0 \mathrm{a}$ & $0.46 \mathrm{a}$ \\
\hline KW 606 & $121.00 \mathrm{ab}$ & $1.8 \mathrm{ab}$ & $3.4 \mathrm{a}$ & $6.1 \mathrm{a}$ & $0.55 \mathrm{a}$ \\
\hline KW 609 & $144.33 \mathrm{a}$ & $1.9 \mathrm{a}$ & 3.1 abcd & $5.4 \mathrm{a}$ & $0.63 \mathrm{a}$ \\
\hline KW 614 & 92.00 cde & $1.6 \mathrm{abc}$ & $2.7 \mathrm{~cd}$ & 5.9 a & $0.59 \mathrm{a}$ \\
\hline KW 619 & $111.00 \mathrm{bcd}$ & $1.8 \mathrm{ab}$ & $2.8 \mathrm{bcd}$ & $5.4 \mathrm{a}$ & $0.65 \mathrm{a}$ \\
\hline KW 635 & 95.67 bcde & $1.9 \mathrm{a}$ & $3.2 \mathrm{abc}$ & $6.3 \mathrm{a}$ & $0.58 \mathrm{a}$ \\
\hline KW 641 & $63.00 \mathrm{f}$ & $1.3 \mathrm{c}$ & $2.5 \mathrm{~d}$ & $5.2 \mathrm{a}$ & $0.54 \mathrm{a}$ \\
\hline KW 651 & 82.00 ef & $2.0 \mathrm{a}$ & $3.3 \mathrm{abc}$ & $5.7 \mathrm{a}$ & $0.58 \mathrm{a}$ \\
\hline
\end{tabular}

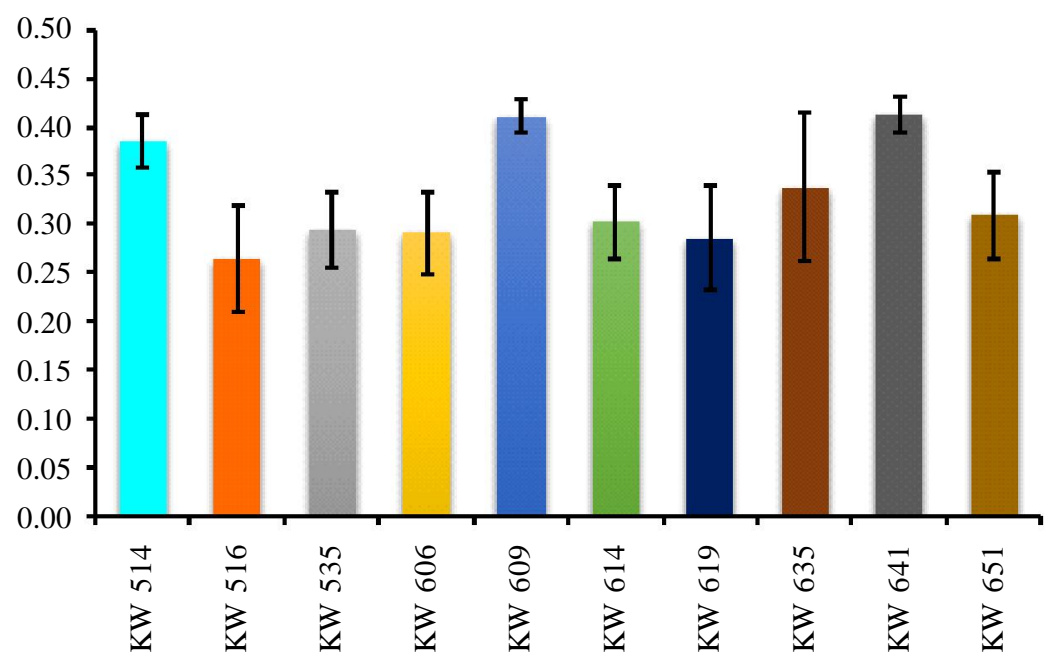

Figure 1. Leaf thickness in several of cocoa clones during prolonged dry season (Mean \pm Standard Deviation) 
Figure 2 showed the water status inside of plant organ. Water status are including relative water content (RWC) and water saturation deficit (WSD). The relative water content is water quantity measurement in tissue compared with saturated condition. Water saturation deficit is water content in tissue compared with saturated condition.

In relative water content parameter showed the differences in each cocoa clone during the prolonged dry season. Highest value of relative water content was shown in KW 641 and KW 535. Similar with the relative content water, water saturation deficit is the opposite from relative water content which indicated the condition of water deficiency compared to saturated condition. On this parameter, KW 641 and KW 535 showed the smallest water deficiency comparing to other clones. Pujiyanto (2013) reported that leaf water saturation deficit represented status of water in leaf at the measurement time and as plant responses to soil water status. Therefore, the variable of water saturation deficit can be used as indicator of plant water status. Erwiyono (2005) reported the plant turgidity of coffee manifested in form of relative water content in dry season where soil moisture is very low, plant turgidity decreased below its critical point $(<82 \%)$ at which $\mathrm{RH}$ also relatively low $(<85 \%)$ so in this plant turgidity also became an indicator of stress plant withered.

Leaf water content can be affected by quality of cell walls in the tissues depicted by osmotic tension of the cells. Winaryo et al. (1997) explained that the osmotic tension of the cell was largely determined by cocoa clones used. Osmotic tension of root cell and leaf could be used as drought stress resistance estimator. Lower osmotic tension of cell will increase the ability to absorb water, on the other hand, in cells with high osmotic tension of the cell, the ability to hold water in cells is also higher.

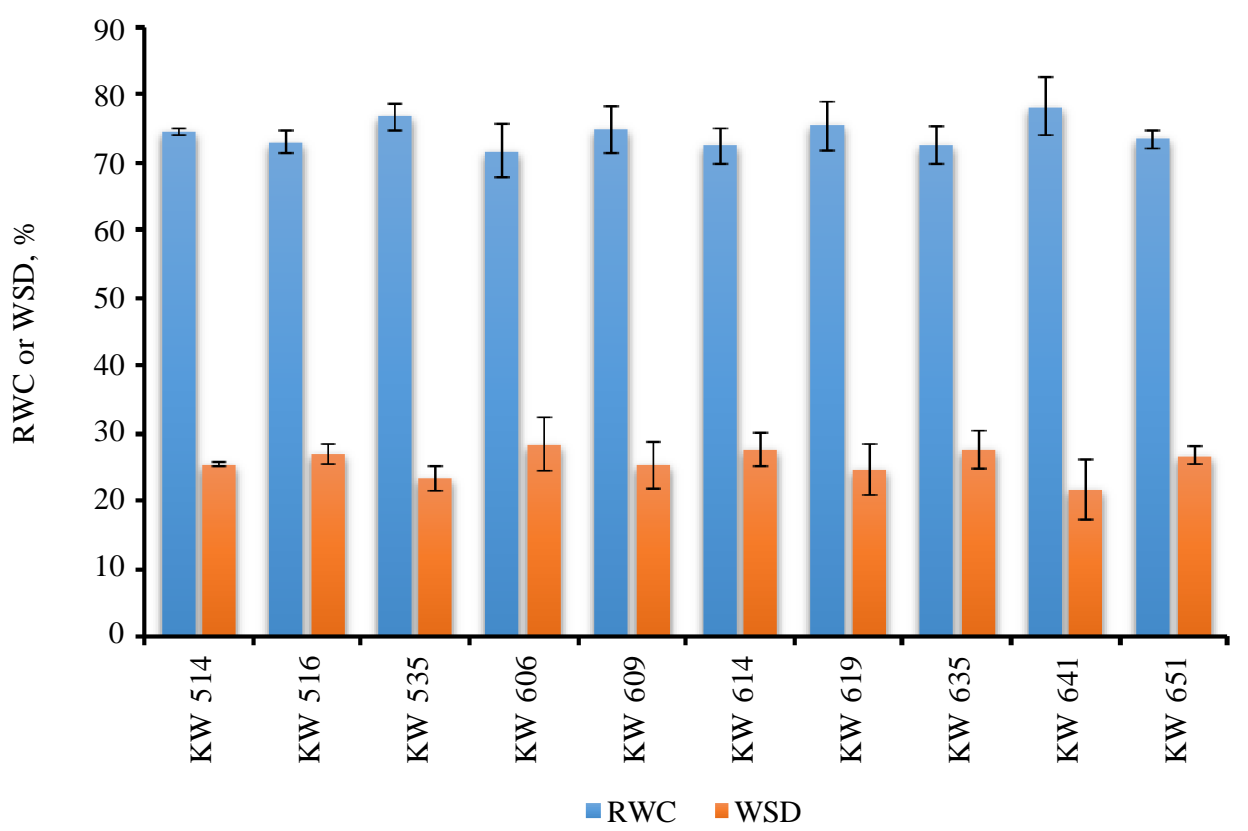

Figure 2. Water relative content and water saturation deficit $(\%)$ in several cocoa clones in prolonged dry season (Mean \pm Standard Deviation) 
One of plant mechanism in order to survive and absorb water in drought stress condition is by osmotic adjusment. In general, cocoa plant accumulate osmolite compound that can decrease the water potential inside of plant body. Bae et al. (2009) reported that proline is the most accumulated compound in cocoa leaf tissue. Figure 3 showed that each clone shows different responses in accumulating proline. KW 641 clone can accumulate high proline compared with the other clones as big as $0.26 \mu \mathrm{mol} . \mathrm{g}^{-1}$. Clone of KW 514, KW 516, KW 619, and KW 651 were also high enough to accumulate proline, but the KW 635 was the clone that lowest to accumulate proline.
To identify the two character group of clones that predicted to have different drought tolerances, it can be analyzed using PCA (Figure 4). The clones that predicted tolerant under drought stress were KW 641, KW 514, KW 516, KW 535, and KW 619, while the clones that including susceptible clones under drought stress were KW 609, KW 614, KW 635, KW 606, and KW 651. Characteristic that affects onto this drought tolerance its showed by direction of PCA scatter plot diagram, such as the higher RWC and leaf proline content, the narrow of width and length of the stomatal opening, also the smaller value of WSD. However, the character of leaf thickness was not significanlly different to the character of drought tolerance.

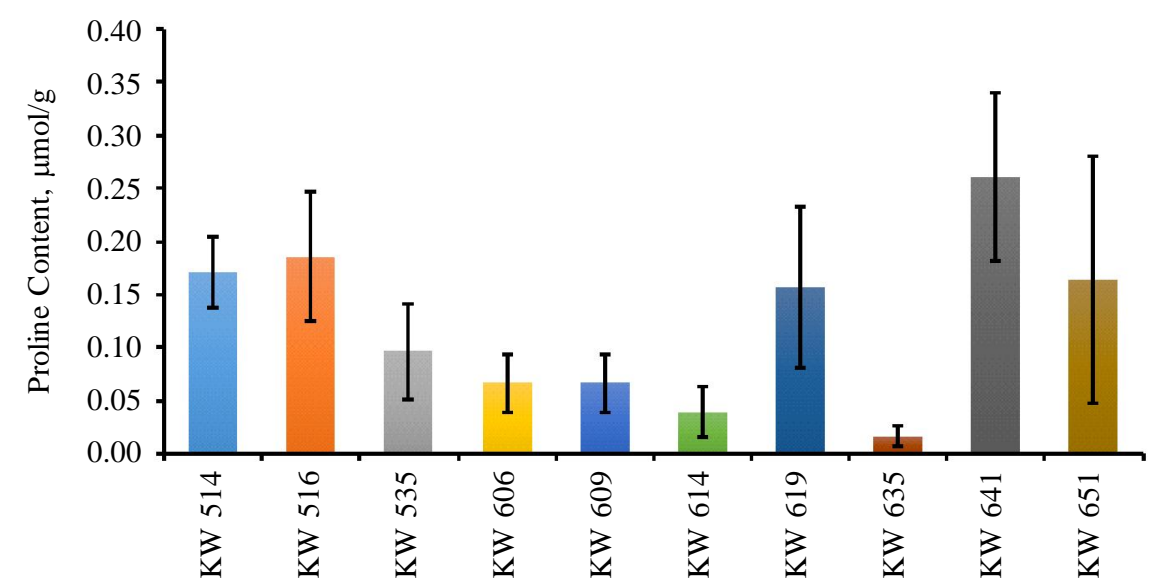

Figure 3. Leaf proline content in several cocoa clone in prolonged dry season (Mean \pm Standard Deviation)

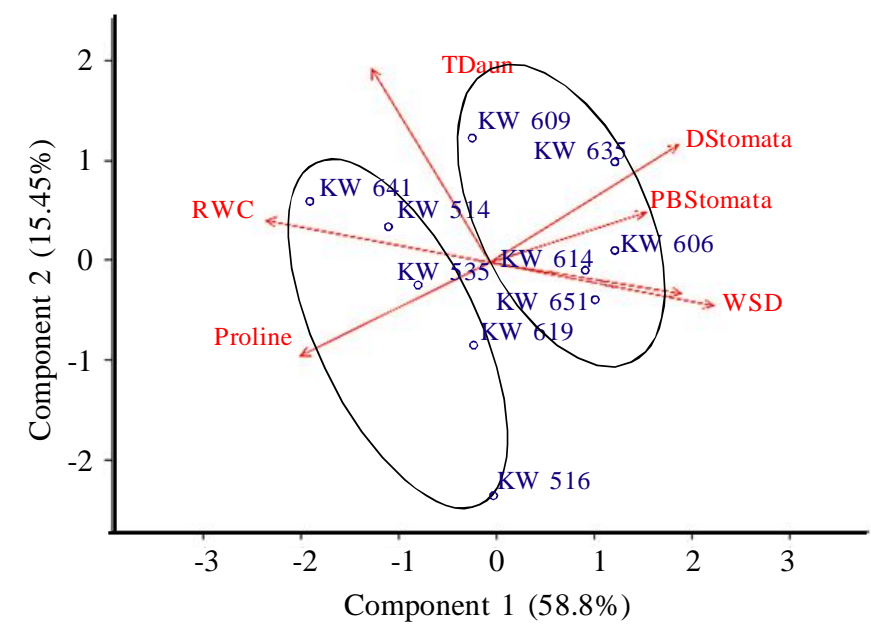

Figure 4. Scatter plot diagram of stomatal character, leaf water status, and leaf proline content in several cocoa clone during prolonged dry season 


\section{CONCLUSION}

There were differences of morphophysiological characters among the clones. The character of leaf thickness were not significanly different to the character of drought tolerance. Hight relative water content, high leaf proline content, low value of width and lenght of opening stomata, and small value of WSD were determining factor of drought tolerant characters of cocoa clones of KW 641, KW 514, KW 535, KW 619, and KW 516.

\section{ACKNOWLEDGEMENTS}

We thank to Herwanto, Gito Nugraha, Arief, and Arik Ermawan helped in compiling data for this research.

\section{REFERENCES}

Abdoellah, S. (1997). Ancaman cekaman air di musim kemarau panjang pada tanaman kopi dan kakao. Warta Pusat Penelitian Kopi dan Kakao, 13, 77-82.

Arve, L.E.; S. Torre; J.E. Olsen \& K.K. Tanino (2011). Stomatal responses to drought stress and air humidity. In: A. Shanker \& B. Venkateswarlu. Abiotic Stress in Plants - Mechanisms and Adaptations. INTECH Open Access Publisher.

Bae, H.; R.C. Sicher; M.S. Kim; S.H. Kim; M.D. Strem; R.L. Melnick \& B.A. Bailey (2009). The beneficial endophyte Trichoderma hamatum isolate DIS $219 \mathrm{~b}$ promotes growth and delays the onset of the drought response in Theobroma cacao. Experimental Botany, 60, 3279-3295.

Bannister, P. (1976). Introduction to Physiological Plant Ecology. Blackwell, Oxford.

Baon, J.B. (1988). Lahan-lahan yang cocok untuk kakao dan kopi. Warta Penelitian Kopi dan Kakao, 7, 17-20.

Brataningtyas, E. (2010). Pengaruh Cekaman Kekeringan terhadap Pertumbuhan
Beberapa Klon Kakao. Skripsi. Universitas Jember, Jember.

Bates, L.; R.P. Waldren \& R.P.I.D. Teare (1973). Rapid determination of free proline for water-stress studies. Plant and Soil, 39, 205-207.

Chibuike, G.U. \& A.J. Daymond (2015). Mycorrhizae inoculation did not influence the response of cocoa seedlings to water stress. American-Eurasuan Journal Agriculture \& Environmental Science, 15, 944-956.

Doheny-Adams, T.; L. Hunt, P.J. Franks, D.J. Beerling \& J.E. Gray (2012). Genetic manipulation of stomatal density influences stomatal size, plant growth and tolerance to restricted water supply across a growth carbon dioxide gradient. Philosophical Transactions of the Royal Society B: Biological Sciences, 367, 547-555.

Drake, P.L.; R.H. Froend \& P.J. Franks (2013). Smaller, faster stomata: scaling of stomatal size, rate of response, and stomatal conductance. Journal of Experimental Botany, 64, 495-505.

Erwiyono, R. (2005). Lengas tanah dan turgiditas beberapa klon kopi Robusta di dataran aluvial berpola hujan musiman. Pelita Perkebunan, 21, 113-130.

Fitter, A.H. \& R.K.M. Hay (1981). Enviromental Physiology of Plant. Academic Press, Inc., London.

Galmés, J.; J.M Ochogavía; J. Gago; E.J. Roldán; J. Cifre \& M.A. Conesa (2013). Leaf responses to drought stress in mediterranean accessions of Solanum lycopersicum: Anatomical adaptations in relation to gas exchange parameters. Plant, Cell, and Environment, 36, 920-935.

ICCO (2010). Impact of El Niño/La Niña Weather Events on The World Cocoa Economy. One Hundred and Forty-Second Meeting, London, 13-17 September 2010.

Johnson, R. (2007). Control of leaf stomatal opening. Colby Journal Research and Methodology, 9,14-17. 
Kacou, M.B.; A. Alban \& S.E.A.K.B. Hebbar (2016). Morpho-physiological criteria for assessment of two month old cocoa (Theobroma cacao L.) genotypes for drought tolerance. Indian Journal Plant Physiology, 21, 23-30.

Keil, A.; M. Zeller; A. Wida; B. Sanim \& R. Birner (2008). What determines farmers resilience towards ENSO-related drought? An empirical assessment in Central Sulawesi, Indonesia. Climatic Change, 86, 291.

Lawson T. \& M.R. Blatt (2014). Stomatal size, speed, and responsiveness impact on photosynthesis and water use efficiency. Plant Physiology, 164, 1556-70.

Lestari, E.G. (2005). Hubungan antara kerapatan stomata dengan ketahanan kekeringan pada somaklon padi Gajahmungkur, Towuti, dan IR 64. Biodiversitas, 7, 44-48.

Maréchaux, I.; M.K. Bartlett; L. Sack; C. Baraloto; J. Engel; E. Joetzjer \& J. Chave (2015). Drought tolerance as predicted by leaf water potential at turgor loss point varies strongly across species within an Amazonian forest. Functional Ecology, 29, 1268-1277.

McDowell, N.; W.T. Pockman, C.D. Allen; D.D. Breshears; N. Cobb; T. Kolb; J. Plaut; J. Sperry; A. West; D.G. Williams \& E.A. Yepez (2008). Mechanisms of plant survival and mortality during drought: why do some plants survive while others succumb to drought?. New Phytologist, 178, 719-739.

Mommer, L. (1999). The Water Relations in Cacao (Theobroma cacao L.): Modelling Root Growth and Evapotranspiration. Thesis. Wageningen Agricultural University, Department of Theoretical Production Ecology, The Netherlands.

Outlaw, W.H. (2003). Integration of cellular and physiological functions of guard cells. Critical Reviews in Plant Sciences, 22, 503-529.
Oyekale, A.S. (2015). Climate change induced occupational stress and reported morbidity among cocoa farmers in South-Western Nigeria. Annals of Agricultural and Enviromental Medicine, 22, 357-361.

Pujiyanto (2013). Respons tanaman kopi arabika pada tanah andisol terhadap aplikasi bahan organik. Pelita Perkebunan, 29, 182-196.

Rada, F.; R.E. Jaimez; C.F. Garcia-Nunez; A. Azocar \& M. Ramirez (2005). Water relations and gas exchange in Theobroma cacao var. Guasare under periods of water deficit. Review Faculty Agronomy, 22, 2-9.

Sakiroh, I.; Sobari \& M. Herman (2015). Teknologi mengurangi dampak perubahan iklim pada kakao di lahan kering. Sirinov, 3 , 55-66.

Schwendenmann, L.; E. Veldkamp; G. Moser; H. Dirk; M. Kohler; Y. Cloughs \& S. Oliver (2016). Effects of an experimental drought on the functioning of cacao Agroforestry system, Sulawesi, Indonesia. Global Change Biologu, 16, 1515-1530.

Soedarsono (1997). Respon fisiologi tanaman kakao terhadap cekaman air. Warta Puslit Kopi dan Kakao, 13, 96-109.

Winaryo, A.; Iswanto \& H. Winarno (1997). Kajian penggunaan tegangan osmotik dan kerapatan stomata sebagai kriteria seleksi klon kakao tahan cekaman air. Pelita Perkebunan, 13, 63-70.

Wood, G.A.R. (1975). Cocoa. Tropical Agriculture Series, $3^{\text {rd }}$ Edition, Longman Group Limited, London,

$$
* * 0 * *
$$

